\title{
EVALUATION OF ANTIMICROBIAL ACTIVITY AND PHYTOCHEMICALS ANALYSIS OF WHOLE PLANT EXTRACT OF VINCA ROSEA
}

\author{
ANGELIN JEBAMALAR JAYARAJ ${ }^{1}$, JOTHI UCHIMAHALI ${ }^{1}$, THIYAGARAJAN GNANASUNDARAM ${ }^{2,3}$, \\ SIVAKUMAR THIRUMAL ${ }^{2,4 *}$
}

${ }^{1}$ Department of Botany, Bharathiar University, Coimbatore, Tamil Nadu, India. ${ }^{2}$ Department of Botany, Annamalai University, Cuddalore, Tamil Nadu, India. ${ }^{3}$ Department of Botany, Government Arts College, Kumbakonam, Tamil Nadu, India. ${ }^{4}$ Department of Botany, Thiru A. Govindasamy Government Arts College, Viluppuram, Tamil Nadu, India. Email: drtsivanano@gmail.com

Received: 14 May 2019, Revised and Accepted: 19 June 2019

ABSTRACT

Objectives: The aim of this research work was to find out the antibacterial activity and phytochemical analysis of whole plant extracts (shoot, flower, and root) of Vinca rosea.

Methods: In recent work, phytochemicals were extracted from various parts of the plants using various solvents ethyl acetate (ETOAC), ethanol (ETOH), and dimethyl sulfoxide (DMSO). These phytochemicals contain alkaloids, terpenoids, tannins, flavonoids, aminoacids, saponins, aromatic acids, phenolic compounds, triterpenoids, xantho proteins, PHILOBATININS, carbohydrate, reducing sugar, and proteins; and they were separated by the standard methods. Moreover, antimicrobial activities of methanolic separation were determined by a different species of bacteria and fungi. Agar well-diffusion method was used for the antimicrobial activity, and also analyzed the zone of inhibition.

Results: The evaluation of phytochemical screening of extracts indicated the existence of alkaloids, terpenoids, tannins, flavonoids, aminoacids, saponins, aromatic acids, phenolic compounds, triterpenoids, xantho proteins, philobatinins, carbohydrate, reducing sugar, and proteins. All the tested bacteria and fungi were controlled efficiently, and the activities of the shoot extracts were better compared to flower and root extracts. ETOH extract of the shoot exhibited highest antifungal activity against Candida albicans, (17.34 mm), followed by Candida krusei (16.12 mm), Aspergillus niger (15.76), Mucor sp. (14.67 mm), and Rhizopus oryzae (13.46 mm), ETOH extract of the shoot exhibited highest antibacterial activity), when compared to flower and root extracts against Staphylococcus aureus (12.77 mm), followed by Pseudomonas aeruginosa (11.67 mm), Salmonella abony (10.23 mm), Escherichia coli $(9.65 \mathrm{~mm})$, Micrococcus luteus ( $8.95 \mathrm{~mm}$. V. rosea shoot extracts highlighted effective antifungal activities compared with flower and root extracts against all the tested bacteria.

Conclusion: Current studies have shown that the V. rosea plant contains significant antimicrobial activities in the ETOH extracts. The strong antifungal and antibacterial activities of $V$. rosea are owing to the presence of saponin, tannins, and flavonoids present in.

Keywords: Vinca rosea, Alkaloids, Phenolic compounds, Antibacterial, Antifungal activity.

(C) 2019 The Authors. Published by Innovare Academic Sciences Pvt Ltd. This is an open access article under the CC BY license (http://creativecommons. org/licenses/by/4. 0/) DOI: http://dx.doi.org/10.22159/ajpcr.2019.v12i8.34124

\section{INTRODUCTION}

Ayurveda is an important system of a substitute and complementary medicine. Various drug formulations are used in the medicine of Ayurvedic systems. In addition to other herbal remedies, large portions of its medicines are native to domestic herbs. The complete and enhanced knowledge of the herbal plants is obligatory for all who work in the Ayurvedic field to find the appropriate plant for a particular disease [1]. In the current years, interest in medicinal plants has increased greatly, and the West has taken this issue seriously [2]. The World Health Organization (WHO) is currently encouraging and promotes folk medical treatment in the National Health Programmes, which are simply available at the cheapest prices and are ethnically accepted. In addition, the WHO estimates that approximately one-third of the world population used herbs and other types of folk medicines to treat the diseases [3]. Plant-based drugs are safe because there are some or no side effects [4]. Furthermore, the lack of quality control information is less acceptable to accept Ayurvedic medicines. The end product analysis profile has an impact on its act and safety [5].

Plant formulations are used mainly for various diseases associated with cancer treatment. Plants produce numerous secondary metabolites including alkaloids, steroids cyanogenic glycosides, flavonoids, saponins, and terpenoids to guard for themselves from an attack of obviously occurring disease, pests, pests, and environmental stresses.
These compounds can be separated based on the activity of the compound and solvents used for extraction [6,7]. Often herbal plants used in traditional medicine have many bioactive compounds that can prevent many infectious diseases or treated as alternative treatments. Medicinal plants are treated as a useful and safe alternative for artificial antibiotics $[8,9]$

$V$. rosea is an associated sub green traditional medicinal plants that grow up to $1 \mathrm{~m}$ height. The leaves are elliptic, egg-shaped $2.5-9.5 \mathrm{~cm}$ and 1-3.5 cm. The midrib has a wide and green hairless into a little petiole $1-1.8 \mathrm{~cm}$ to arranged in the opposite pairs. The flowers have different colors such as white, dark pink to a dark red in the center and basal tube length $2.5-3 \mathrm{~cm}$, corolla about $2-5 \mathrm{~cm}$ diameter by five petals lobe. Fruits are $2-4 \mathrm{~cm}$ long and a couple of follicles and $3 \mathrm{~mm}$ broad [10].

$V$. rosea (Apocynaceae) is a traditionally important medicinal plant, which contains more than 70 various types of alkaloids and chemotherapeutic agents that are useful in treating different types of cancers such as, breast cancer, lung cancer, melanomas, uterine cancer, and Hodgkin and non-Hodgkin's lymphoma. Commonly, it is known as $V$. rosea, Ammocellia rosa, and Lochnera rosea. Indian originated herbal plants such as Catharanthus roseus grows naturally in the Indian subcontinent in southern Asia [11]. The C. roseus can be grown by two 
common names for cultivated, which is named on the basis of their flower colors, pink: rose, white: alpha [10] Conventionally, the leaves of the $C$. roseus are used as medicines to treat the following diseases, which includes rheumatism, menorrhagia, dyspepsia, indigestion, diabetes, dysmenorrheal, hypertension, menstrual disorders, cancer, skin diseases, bleeding, and diarrhea.

Vinka rosea leaves include more than 70 types of chemicals compounds such as indole types of alkaloids, ajmalicine, serpentine, and reserpine. Owing to the presence of these alkaloids in the C. roseus, it has antihypertensive and antispasmodic properties. The important types of alkaloid, vinblastine produced by $C$. roseus are owing to its anti-tumor function and are widely used in the pharmaceutical industry [12]. C. roseus were developed to produce a modern chemotherapeutic agent for their pain-relieving activities [13].

Apocynaceae is native toward the Caribbean and is used to treat an assortment of diseases. European herbs are used in different conditions as such as headache for a traditional remedy and for diabetes. They disrupt the anatomical structure of normal living tissues and its functions due to physical, chemical, microbiology, or immunization of diseases; they act as a wound healer. It has been tried to prove the antibacterial activity of $C$. roseus by isolating the medical components experimentally. As a result, many antibiotics are produced against wound disease, but they have undesirable adverse effects [14]. Perhaps, most medicinal plants may be natural antioxidants, such as tannins, phenolics, and flavonoids than dietary plants.

$V$. rosea contains major amounts of the volatile and phenolic compound as well as caffeoylquinic acids and flavorful glycosides which are recognized for antioxidant activities. It plays a vital role in the body defense system that acts as antioxidants against reactive oxygen species, which gets damaged with products during the normal cell aerobic respiration. The concentration of free radicals can cause illnesses such as ischemia, asthma, arthritis, inflammation, neurodegeneration, Parkinson's disease, mongolism, the aging process, and probably dementia [9].

Thus, new drugs expect herbal resources for better and cheaper alternatives to natural products. Treatment standards for these plants are fixed in various phytochemicals with constructing a stable physiological activity in the human body [15]. Different parts of $C$. roseus have various types of application, specifically used in traditional medical practice. The major research of this work was to evaluate the phytochemical and antimicrobial activities in the whole plant extract of the $V$. rosea.

\section{METHODS}

\section{Plant materials}

The uprooted plants (shoot, flower, and root) were collected at Bharathiar University, Coimbatore 2013-2014 Tamil Nadu, India. The plant was identified by the Department of Botany, Annamalai University, Tamil Nadu, India. Uprooted entire plants are separated and washed out in tap water, dried in the shade and finely powdered, stored in a JIBLOCK COVERED.

\section{Chemicals}

All chemicals were acquired by the SD Chemicals Company Mumbai and every chemical was Analytical grade.

\section{Phytochemical screening}

The phytochemical analysis of the solvent extracts through ETOH, $\mathrm{MEOH}$, and DMSO of a $V$. rosea entire plant extract was analyzed by standard methods as described [14-16]. The extract was analyzed to obtain secondary metabolites such as alkaloids, terpenoids, tannins, flavonoids, aminoacids, saponins, aromatic acids, phenolic compounds, triterpenoids, xantho proteins, philobatinins, carbohydrate, reducing sugar, and proteins.

\section{Fungal strains and inoculum quantification}

The selected plant, fungal pathogens, R. oryzae (MTCC No. 3690), Mucor sp. (MTCC No.3340), A. niger (MTCC No. 5889), C. krusei (MTCC No. 3020), and C. albicans (MTCC No. 7315) were collected from the Department of Medical Microbiology, Rajah Muthiah Medical College and Hospital, Annamalai University, Tamil Nadu, India. Selected fungi, plants are important in the disease fungi with economic impact. Fungal strains were retained on potato dextrose (PD) agar. Revised hemocytometer cell counting is used to calculate the number of cells in fungal culture [17]. The inoculum preparation involved the development of fungi on PD agar slants for a week at $35^{\circ} \mathrm{C}$. The slant was wiped with a sterile cotton swap and replaced with a sterile tube with a new PD broth $(50 \mathrm{ml})$. Steril tubes were delayed by $5 \mathrm{~min}$, and a reaction was made to evaluate the number of cells by a microscopic record with a hemocytometer. The final inoculums concentration was maintained at approximately $1.0 \times 10^{6}$ cells $/ \mathrm{ml}$.

\section{Determining antifungal activity}

Every well was filled with plant extracts $(100 \mathrm{~mL})$ serially diluted $50 \%$, and it contains with water in 96 well microtiter plates, and $100 \mathrm{ml}$ of fungal cultures were included [18]. Amphotericin B was used as an antibiotic indication, and $100 \%$ acetone was used as a negative control. Amphotericin B antibiotics were used and referenced $100 \%$ acetone was a negative control. The previous concentration of acetone in the microplate showed no effect on the fungi development [19]. $40 \mathrm{ml}$ of $0.2 \mathrm{mg} / \mathrm{ml} \mathrm{p}$-iodonitrotetrazolium violet (INT) was dissolved in water and filled to the microplate well. The coated microplate was incubated for 3-5 days in a plastic bag. The $100 \%$ humidity was kept in the plastic bag at $35^{\circ} \mathrm{C}$ later sealing the plastic bag to minimize fungal contamination in the lab. The least concentration of plant extracts was listed to MIC that could prevention of antifungal growth. Colorless tetrazolium salt received an electron and inhibited with a red-colored formation developed with biological active organisms [18]. The growth of fungal cell prohibited to a well-known standard solution is a clear or considerable reduction in the harshness of the color later then attached in the INT.

\section{Antibacterial activity}

In vitro antibacterial strains of $M$. luteus, E. coli, S. abony, P. aeruginosa, and $S$. aureus were used and maintained in nutrient agar (HiMedia, Mumbai) slants at $4^{\circ} \mathrm{C}$. Muller-Hinton agar (HiMedia, Mumbai) plates had been prepared, sterilized, solidified, and swabbed uniformly. The antibacterial activity evaluation of aqueous solvents ETOAC, and ETOH, DMSO, was determined by techniques of agar well-diffusion methods. Different concentrations of aqueous solvent 20, 70, and $120 \mu \mathrm{l}$ have loaded into the wells of each plate. All bacterial strains are (M. luteus, E. coli, S. abony, P. aeruginosa, S. aureus, collected from Rajah Muthiah Medical College, Annamalai University, Annamalai Nagar. After incubating the plates at $37^{\circ} \mathrm{C}$ for $24 \mathrm{hrs}$ the inhibited area was measured ( $\mathrm{mm}$ ), and maintains for triplication.

\section{Statistical analysis}

The experiments are performed by triplicates, and the results are expressed as mean \pm standard deviation. Statistical analysis was made by origin software (Origin Pro evaluation, 2018).

\section{RESULTS AND DISCUSSION}

Qualitative phytochemical analysis

The phytochemicals analyzed in the shoot, flower, and root $V$. rosea whole plants extracts examined the presence, absence of bioactive compounds was listed (Tables 1 and 2).

The current studies confirmed the presence of alkaloids, tannins, flavonoids, saponins, phenolic compounds, triterpenoids, amino acids, protein, carbohydrate, reducing sugars, and phlobatannins was observed in shoot extracts while terpenoids, aromatic acids, and xanthoprotein, were absent. The shoot and flower and root extract of $V$. rosea showed negative results for terpenoids and xanthoprotein, as reported in Solanum torvum [20]. The shoot extract showed positive 
results for terpenoids, alkaloids, saponins, and sterols, phenols as mentioned in sweet potato, Asparagus racemosus, Elumpotti, Ormocarpum cochinchinense, Datura, Camellia sinensis, Guazuma ulmifolia, V. radiate, and C. roseus [21-29]

\section{Antifungal activity}

The antifungal activity of the $V$. rosea entire plants such as shoot, flower, and root extracts in various solvents was studied with the aid of the agar well-diffusion method against five pathogenic fungal species and measured the zone of inhibition for each fungal strain at various concentration 20,70, and $120 \mu \mathrm{l} / \mathrm{ml}$ as shown in Fig. 1.

In vitro antifungal activity of the shoot extracts of $V$. rosea made with ETOAC, ETOH, and DMSO showed zone of inhibition against totally five fungal pathogens ( $R$. oryzae, Mucor sp., A. niger, C. krusei, C. albicans) while none of the shoot, flower extracts made with three different solvents showed inhibition zones.

Herein, we report the antifungal activity of phytochemical extracts using ETOAC, ETOH, and DMSO, from shoot, flower, and root of $V$. rosea. It was found effective against $R$. oryzae, Mucor sp., A. niger, C. krusei, C. albicans. In this study, it is observed that the zone of inhibition antifungal (C. albicans) activities of shoot, flower, and root ETOH extract $(17.34 \pm 0.51,12.12 \pm 0.40$, and $13.02 \pm 0.41 \mathrm{~mm}$ at 20,70 , and
$120 \mu \mathrm{l} / \mathrm{ml}$ concentration, respectively) increased proportionately with the increase in the concentration of phytochemical extracts made using three different solvents from shoot, flower, and root of $V$. rosea.

ETOHs solvent extracts of shoot of $V$. rosea showed maximum inhibitory activity against selected fungi than ETOAC and DMSO. The present results confirmed with the previous study, ETOAC, ETOH, DMSO shoot extract of $V$. rosea which showed potential antifungal activity at $1 \mathrm{mg} /$ disc against to $R$. oryzae, Mucor sp., C. albicans, C. krusei, A. niger, [30]. The methanol and ETOH of the entire plant extract showed potential antifungal activity against to F. equiseti, B. theobromae, and $C$. corchori [31]. The phytochemical screening revealed that plant secondary metabolites present in the extracts can agitate the fungal cell wall and also cause the discharge of cellular components such as ions and intracellular proteins which, in turn, stop the progress of the growth of fungi. The plants metabolites alkaloids, saponins, and tannins are acknowledged for antimicrobial activity has been documented well [32]. Several scientists tried to explain the reasonable mechanism of action of the antimicrobial activity of plant extracts. Triterpenoids or saponins present in the extracts could create pore-like structures and are responsible for the dissipation of membrane electrical potential or membrane proton motive force, and hence, the membrane annihilation occurs [33].

Table 1: Qualitative phytocompounds analysis data in the shoot, flower, and root extracts of Vinca rosea

\begin{tabular}{|c|c|c|c|c|c|c|c|c|c|c|c|}
\hline \multirow[t]{2}{*}{ S.No. } & \multirow{2}{*}{$\begin{array}{l}\text { Parts of plant } \\
\text { Test for }\end{array}$} & \multicolumn{3}{|l|}{ Shoot } & \multicolumn{4}{|c|}{ Flower } & \multicolumn{3}{|l|}{ Root } \\
\hline & & EtoAc & EtoH & DMSO & EtoAc & EtoH & & DMSO & EtoAc & EtoH & DMSO \\
\hline 1 & Alkaloids & + & +++ & + & - & & - & - & + & +++ & + \\
\hline 2 & Terpenoids & - & - & - & - & & - & - & - & - & - \\
\hline 3 & Tannins & ++ & +++ & + & + & + & ++ & + & - & - & - \\
\hline 4 & Flavonoids & + & +++ & ++ & + & + & ++ & ++ & - & - & - \\
\hline 5 & Aminoacids & + & +++ & ++ & + & + & ++ & ++ & + & + & + \\
\hline 6 & Saponins & + & +++ & ++ & + & + & ++ & ++ & + & +++ & ++ \\
\hline 7 & Aromatic acids & - & -+ & - & + & + & + & - & - & - & - \\
\hline 8 & Phenolic compounds & + & +++ & ++ & + & + & ++ & ++ & - & - & - \\
\hline 9 & Triterpenoids & + & ++ & ++ & - & & - & - & - & - & - \\
\hline 10 & Xantho proteins & - & - & - & - & & - & - & - & - & - \\
\hline 11 & Philobatinins & + & +++ & ++ & + & + & ++ & ++ & - & - & - \\
\hline
\end{tabular}

+: Low abundance; ++: Moderate abundance; +++: High abundances; -: Absent, DMSO: Dimethyl sulfoxide, EtoAc: Ethyl acetate, EtoH: Ethanol

Table 2: Macromolecule analysis data in the shoot, flower, and root extracts of Vinca rosea

\begin{tabular}{|c|c|c|c|c|c|c|c|c|c|c|}
\hline \multirow[t]{2}{*}{ S.No. } & \multirow{2}{*}{$\begin{array}{l}\text { Parts of plant } \\
\text { Test for }\end{array}$} & \multicolumn{3}{|l|}{ Shoot } & \multicolumn{3}{|c|}{ Flower } & \multicolumn{3}{|l|}{ Root } \\
\hline & & EtoAc & EtoH & DMSO & EtoAc & EtoH & DMSO & EtoAc & EtoH & DMSO \\
\hline 1 & Proteins & + & + & +++ & + & + & ++ & +++ & ++ & + \\
\hline 3 & Carbohydrate & + & + & +++ & - & - & - & + & +++ & + \\
\hline
\end{tabular}

+: Low abundance, ++: Moderate abundance; +++: High abundances, -: Absent, DMSO: Dimethyl sulfoxide, EtoAc: Ethyl acetate, EtoH: Ethanol

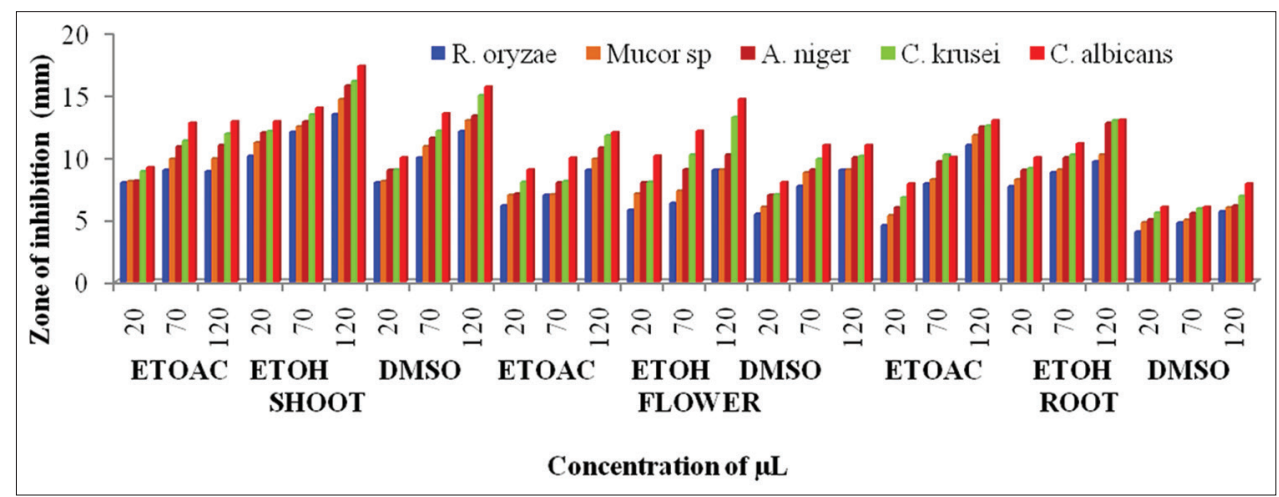

Fig. 1: Inhibition zone of three solvent extracts from shoot, flower, and root extracts of Vinca rosea against five different fungal pathogens 


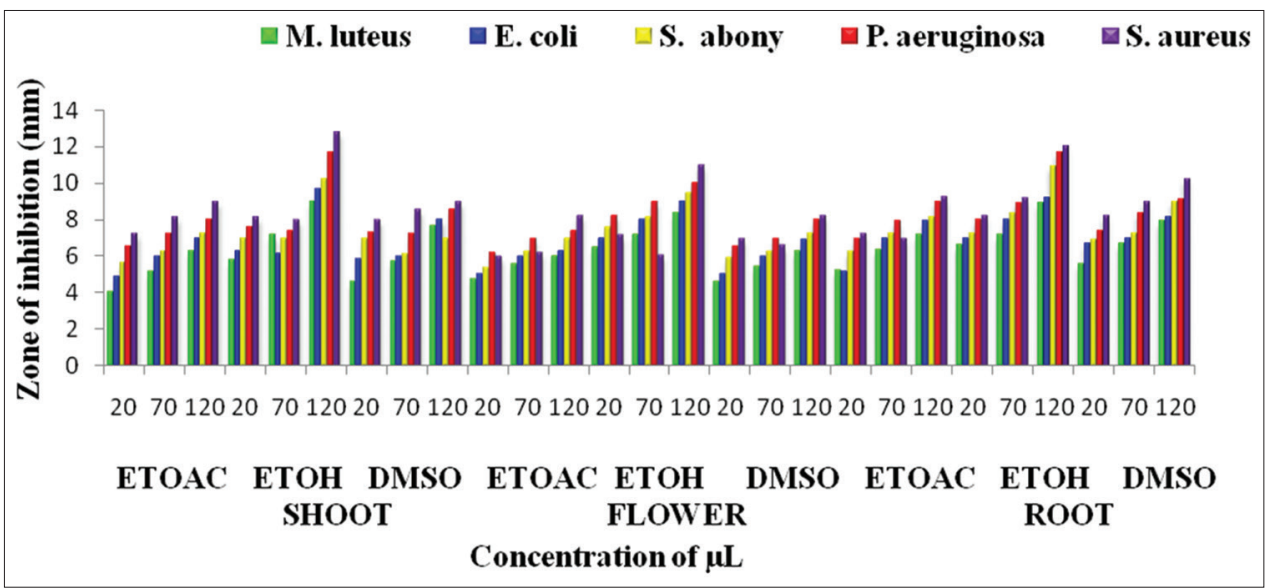

Fig. 2: Inhibition zone of three solvent extracts from shoot, flower, and root extracts of Vinca rosea against five different bacterial pathogens

\section{Antibacterial activity}

Organic solvents (ETOAC, ETOH, DMSO of shoot extracts displayed more pronounced antibacterial activity than flower and root extract. Antibacterial activity exhibited decreased in the order of the shoot, flower, and root extracts. The maximum zone of inhibition $(12.77 \pm 0.42 \mathrm{~mm})$ was exhibited by ETOH shoot extract of $V$. rosea. The ETOAC, ETOH, DMSO, shoot extract confirmed maximum area of inhibition in the various concentrations $(20,70,120 \mu \mathrm{l} / \mathrm{ml})$ against flower and root as shown in Fig. 2.

The potential capability of secondary metabolism is to shape complex extracellular proteins and within the cell wall of microorganisms [34]. The prevention effect of methanol leaf extract, on the increased bacteria inhibition, may be due to the best solubility of these secondary metabolites, which can cause antibiotic compounds [35]. The organic solvent of the whole plant extract (shoot) render greater antibacterial ability than the shoot and flower extract. This result can be recognized to the polarity of the solvent used for extraction, essential bioactivity, and ability to diffuse in media utilized in assay $[36,37]$.

The current investigation on phytochemical tests observed alkaloids, terpenoids, tannins, flavonoids, aminoacids, saponins, aromatic acids, phenolic compounds, triterpenoids, xantho proteins, philobatinins, carbohydrate, reducing sugar, and proteins in the tested solvent extracts. These metabolites of phenolic compounds may be attributed to the potential therapeutic activity of plants as the treatment of different diseases [38]. Steroids have strong antibacterial properties [39-41]. These findings were the source of the current research, In V. rosea ETOH shoot extract has an excellent antimicrobial activities, it is known as phenolic compounds, saponins, tannins, and glycosides.

\section{CONCLUSION}

The current study justified that antimicrobial activity was evaluated based on their use in ethnobotanical literature using traditional herbal plants. From the results, it was concluded that ETOH shoot extracts of $V$. rosea showed potential antimicrobial activity against pathogenic organism. Hence, the ETOH shoot extract of $V$. rosea has effective bioactive compounds responsible for antifungal, antibacterial activities. Therefore, further investigations on combined isolation, toxicology, and the effective compound require clinical trials and deserve extensive research.

\section{ACKNOWLEDGMENTS}

The authors are thankful to the Head, Department of Botany, Annamalai University, Annamalainagar, for providing the laboratory facilities.

\section{AUTHOR S' CONTRIBUTIONS}

TS designed conceived the thought, participated in designing, supervised, monitored the work progress. AJ and UJ conducted the experiments; TS, GT, and AJ drafted the manuscript for publication. All authors read and approved the final manuscript.

\section{CONFLICTS OF INTEREST}

The authors declare no conflicts of interest.

\section{REFERENCES}

1. Ballabh B, Chaurasia OP. Traditional medicinal plants of cold desert Ladakh used in treatment of cold, cough and fever. J Ethnopharmacol 2007;112:341-9.

2. Perumal Samy R, Ignacimuthu S, Sen A. Screening of 34 Indian medicinal plants for antibacterial properties. J Ethnopharmacol 1998:62:173-82.

3. Leena KP, Sreelakshmi KS. Phytochemical screening and in vitro cytotoxicity studies of Mussaenda frondosa Linn leaves. Res J Pharm Tech 2017;10:4227-30.

4. Sreesha NN, Alexeyena V, Meenu B, Greeshma R, Neeraja ED. Comparative evaluation of Coriandrum sativum Linn. And Apius graveolens for antimicrobial activity. Res J Pharm Technol 2017;10:541-4.

5. Shaikh S, Jain V. Development and validation of RP-HPLC method for the simultaneous determination of curcumin, piperine and camphor in an ayurvedic formulation. Int J Pharm Pharm Sci 2018;10:115-21.

6. Cragg GM, Newman DJ. Plants as a source of anti-cancer agents. J Ethnopharmacol 2005;100:72-9.

7. Shalini S, Prema S. Phytochemical screening and antimicrobial activity of plant extracts for disease management. Int J Curr Sci 2012;6:209-18.

8. Chinnavenkataraman G, Rajendran S. In vitro antibacterial activity and phytochemical analysis of Catharanthus roseus (Linn.) G. Don. Asian Pac J Trop Biomed 2012;8:155-8.

9. Sarabjot K, Poonam M. Study of total phenolic and flavonoids content, antioxidant activity and antimicrobial properties of medicinal plants. J Microbiol Exp 2014;1:1-6.

10. Monika S, Vandana S. Catharanthus roseus a review of potential therapeutics properties. Int J Pure App Biosci 2013;1:139-42.

11. Kumar KC, Singhal RA, Sharma GK, Vyas VK. Analysis of antioxidant activity of Catharanthus roseus L. And it's association with habitat temperature. Asian J Exp Biol Sci 2012;3:706-13.

12. Rischer H, Oresic M, Seppänen-Laakso T, Katajamaa M, Lammertyn F, Ardiles-Diaz W, et al. Gene-to-metabolite networks for terpenoid indole alkaloid biosynthesis in Catharanthus roseus cells. Proc Natl Acad Sci U S A 2006;103:5614-9.

13. Kumari K, Gupta S. Phytopotential of Cathanthus roseus L.(G.) Don. Var. "Rosea" and "Alba" against various pathogenic microbes in vitro. Int J Res Pure Appl Microbiol 2013;3:77-82.

14. Sheeraz AW, Sudhansud DD, Sharma JT, Mushtaq A. Antimicrobial activity of Catharanthus rosrus. Chem Mat Res 2013;3:61-3.

15. Edeoga HO, Okwu DE, Mbaebie BO. Phytochemical constituents of 
some Nigerian medicinal plants. Afr J Biotech 2005;4:685-8

16. Harbone JB. Phytochemical Methods-A Guide to Modern Technique of Plant Analysis. London: Chapmen and Hall; 1998. p. 182-90.

17. Aberkane A, Cuenca-Estrella M, Gomez-Lopez A, Petrikkou E, Mellado E, Monzón A, et al. Comparative evaluation of two different methods of inoculum preparation for antifungal susceptibility testing of filamentous fungi. J Antimicrob Chemother 2002;50:719-22.

18. Eloff JN. Which extractant should be used for the screening and isolation of antimicrobial components from plants? J Ethnopharmacol 1998;60:1-8

19. Eloff JN, Picard J, Masoko P. Resistance of animal fungal pathogens to solvents used in bioassays. S Afri J Bot 2007;73:667-9.

20. Prakash S, Jain AK. Antifungal activity and preliminary phytochemical studies of leaf extract of Solanum nigrumlinn. Int J Pharm Pharm Sci 2011;3:352-5.

21. Kalita L, Dash B, Borah U, Deka J, Dash S. Preliminary phytochemical analysis and antimicrobial activity ethanolic extracts of dried fruits of Solanum torvum (Family-Solanaceae). Int J Curr Pharm Res 2017;9:123-6.

22. Sivakumar T. Phytochemical screening and gas chromatographymass spectroscopy analysis of bioactive compounds and biosynthesis of silver nanoparticles using sprout extracts of Vigna radiata L. and their antioxidant and antibacterial activity. Asian J Pharm Clin Res 2019;12:180-4.

23. Sivakumar T, Gajalakshmi D. Phytochemical screening and gc-ms analysis of root extract from Asparagus racemosus L. Int J Pharm Sci Res 2014;5:5245-9.

24. Sivakumar T, Gajalakshmi D. In vitro antioxidant and chemical constituents from the leaves of Ormocarpum cochinchinense elumbotti. Amar J Plant Physiol 2013;8:114-22.

25. Sivakumar T, Gajalakshmi D. Gas chromatography-mass spectroscopy analysis of Ormocarpum cochinchinense leaf extract-traditional bone healing plants. Int J Pharm Res Bio Sci 2014;3:352-9.

26. Sivakumar T, Panneerselvam R. Triadiadomefon mediated changes in antioxidant and indole alkaloid content in two species of Datura. Amar J Plant Physiol 2011;6:252-60.

27. Senthilkumar SR, Sivakumar T. Green tea (Camellia sinensis) mediated synthesis of zinc oxide (ZNO) nanoparticles and studies on their antimicrobial activities. Int J Pharm Pharm Sci 2014;6:461-5.
28. Bhavani D, Malairajan S, Vanitha V. Physicochemical, phytochemicals and antioxidant evaluation of Guazuma ulmifolia fruit. Int J Pharm Pharm Sci 2018;10:87-91

29. Divya P, Bhawana P, Sheetal S. Phytochemical analysis and antimicrobial activity of catharanthus roseus. Ind J Sci Res 2017; 12: 124-127.

30. Nagarasan S, Boominathan M. Perspective pharmacological activities of Leucas aspera: An indigenous plant species. Indo Amari J Pharm Res 2016; 6:6567-72.

31. Akter M, Khan MA, Muhsin MD, Hamid K, Ullah MO, Bulbul IJ. In vitro studies on antibacterial, antifungal, and cytotoxic properties of Leucas aspera. Bio Med 2012;4:183-7.

32. Tschesche R. Advances in the chemistry of antibiotics substances from higher plants. Pharm Phytochem 1970;3:274-89.

33. Netala VR, Ghosh SB, Bobbu PL, Dandu A, Tartte V. Triterpenoid saponins: A review on biosynthesis, applications and mechanism of their action. Int J Pharm Pharm Sci 2015;7:24-8.

34. Kuete V, Nguemeving JR, Beng VP, Azebaze AG, Etoa FX, Meyer M, et al. Antimicrobial activity of the methanolic extracts and compounds from vismia laurentii de wild (Guttiferae). J Ethnopharmacol 2007;109:372-9.

35. Ikigai H, Nakae T, Hara Y, Shimamura T. Bactericidal catechins damage the lipid bilayer. Biochim Biophys Acta 1993;1147:132-6.

36. Jigna PA, Darshana JA, Sumitra CH. Efficacy of aqueous and methanol extracts of some medicinal plants for potential antibacterial activity. Turk J Biol 2005;29:203-10.

37. Sivakumar T, Gajalakshmi D, Subramanian VK, Palanisamy K. Tuber extract mediated biosynthesis of silver nanoparticles and its antioxidant, antibacterial activity. J Biol Sci 2015;15:68-7.

38. Hatil H, Kamali EL, Ehsan M, Karim EL. Evaluation of antibacterial activity of some medicinal plants used in Sudanese traditional medicine for treatment of wound infections. Acad J Plant Sci 2009;2:246-51.

39. Yadav RN, Munin A. Phytochemical analysis of some medicinal plants. J Phytol 2011;3:10-4

40. Jothi U, Anjelin J, Gajalakshmi D, Sivakumar T. Phytochemical analysis, and evaluation of antimicrobial activity in the whole plant extracts of Gloriosa superba. Asian J Pharm Clin Res 2019;12:245-9.

41. Sivakumar T, Gajalakshmi D. FT-IR analaysis and in vitro antibacterial activity of Ormocarpum cochinchinense (elumbotti). Int J Pharm Biol Arch $2019 ; 10 \cdot 78-82$ 